\title{
AC 2010-1939: LEARNING WITH THE STUDENTS: CHEMICAL ENGINEERING STUDENTS HELP DESIGN AND SHAPE DELIVERY OF INSTRUCTIONAL INFORMATION FOR THEIR DISCIPLINE.
}

\section{Mary Strife, West Virginia University}

Mary Strife has been the director of the Evansdale Library at West Virginia University since 2002. She began at WVU in 1995 as Coordinator and Head of the Physical Sciences and Mathematics Libraries. Her career has included science and/or engineering librarian positions at Cornell University, Syracuse University, the University of Rochester, and SUNY Institute of Technology at Utica/Rome. 


\title{
Learning with the Students: Chemical Engineering Students Help Design and Shape Delivery of Instructional Information for Their Discipline
}

\begin{abstract}
During the last year and a half, the West Virginia University Libraries purchased LibGuides, a web-based subject guide template, to make important research and study information available in one convenient place for our students and faculty. The engineering librarian decided to focus on chemical engineering for the first focused engineering guide. The development of the guide became an opportunity to invite senior chemical engineering students to participate in suggesting content for the guide and to use and critique any online/video tutorials that would complement it. Since Chem Eng (ChE) 455/456 Chemical Process Design 1 and 2, are taken by senior chemical engineering students at this institution, one of the professors allowed us to meet with the members of the senior class. Students were aware that the research information in the guide and tutorials would be of more use to students in successive classes since this would be the design phase of the process. The students' horizons are expanding because the LibGuide and tutorials introduced them to information and resources that they may not have had knowledge been of, making the students more aware of the options available for research in their field. The librarian is gaining knowledge at the same time, learning to use Adobe Captivate, exploring video options, operating a Flip camera and editing video. The entire experience has made the librarian more sympathetic to users, especially those less comfortable with technology. A description of the process follows. Student input is critical to the usability of the guide and tutorials.
\end{abstract}

\section{Introduction}

The WVU Libraries' information literacy efforts are becoming more visible on the campus. The Libraries' dean and the Provost's Office have demonstrated the importance of information literacy through its inclusion in the current strategic plan and with financial support for faculty summer stipends to work with librarians to create course-related instruction modules. ABET's emphasis on literacy adds another reason to refocus efforts on providing instructional options to our engineering students. We needed to develop different methods to get instruction to our engineering students since we know that they spend very little time in the library building, and we have minimal contact with them for one shot instruction sessions. The goal is to the best way to provide information to students in short, to-the-point explanations that could be delivered on demand. We have experience with the traditional methods of delivery but very little with online and video options. So this became an opportunity for us to learn at the same time.

\section{Literature review}

There are reviews about LibGuide with some mention is other articles about its use. There are a good number of articles that describe using online or video tutorials generally, with some fascinating articles about various video tutorials for students in engineering and the sciences. Jack Maness from the University of Colorado, Boulder published an article in the Summer 2006 Issues in Science \& Technology Libraries (ISTL) that evaluated streaming video used to deliver 
instruction to engineering students in the distance education program ${ }^{6}$. Barsky and Lindstrom wrote an article in the Fall 2008 issue of ISTL about podcasting at the University of British Columbia $^{1}$. Berger discussed a podcasting pilot project at the University of Virginia ${ }^{2}$. Roberts and Bhatt wrote of their use of WebCT to deliver instructional online tutorials to engineering students at Drexel University (2007) ${ }^{10}$. These are options that we can explore as we go along. Two options for creating online video tutorials are Captivate and Camtaisia. One selects the option based on availability and whether or not it fits the need of the project.

\section{Overview}

At the beginning, it was decided that tutorials would be done by department, would be accessible from the libraries webpage, and would not be embeded in any Ecampus course modules at this stage. We selected chemical engineering to work on first since one-shot sessions were regularly presented to senior chemical engineering students working on their capstone projects. The Engineering and Patents Librarians came together to pack as much information as possible into an hour and a half session. However, all the students had when they left were handouts and whatever they remembered. Online and video information looked to be a good option since it could be accessed at the time of need, no memory needed. The libraries spend a great deal of money on electronic resources, a good deal of it coming from student fees. It is important that the students know what is available to them and how to use it most effectively.

We have learned through experience that student input during the process is essential so that whatever tutorial is created would be useful to and used by students. The first step involved contacting a professor from the Chemical Engineering department with whom we have worked in the past. This year's senior class is small than usual with only nine students. A brief meeting was held in September to give them a general idea of the plan, and they agreed to give feedback to improve the modules. The students understand that the modules will be used by the students coming after them in the program. In addition to the members of the class, several library student workers would be enlisted when immediate feedback was need.

The LibGuide was created first since the modules were to be accessible from that platform, plus it was easier to get this started and finished relatively quickly. The Patents Librarian gave us permission to use her guide as a template, which gave us something to build from. Sometimes it is simpler to ask to use someone else's work, giving proper credit to the designer, than to invent it from scratch. Individualized training on LibGuides creation came from several colleagues. Then the engineering librarian viewed tutorials several times, which allowed changes to be made to the LibGuide while the information was fresh. For many of us, repetition is important and having several learning methods available is the only way to understand any process.

When it was time to select the video option, we went online to look at other institutions websites to see what had already been done. The module from Penn State ${ }^{8}$ was exceptionally good and was one of the first hits that came up with the search for engineering information tutorials. However, we do not have the kind of technical support or the amount of time needed to do anything like that. We needed to use a product that we had easy access to and required little support from our systems people. The Evansdale Library Instruction Coordinator worked to come up with some alternate ideas that would work for the project we had in mind. She viewed 
the Penn State video and decided we could use Adobe Captivate to do a tutorial for our students. The libraries have access to and experience with Captivate but not Camtasia. This was a new learning opportunity for the engineering librarian since there had never been a reason for her to learn to use Captivate. In this situation, it was more helpful to learn how to use Captivate right before using it to create a video. The action reinforced the learning process. The methods used to learn Captivate were similar to that used for LibGuides. First, the engineering librarian watched the instruction coordinator make a demo video. She allowed her to ask questions while the demo was made, which was very helpful. Then the engineering librarian went through the online tutorials more than once, keeping a list of questions to ask later. A very short demo video was created with the instruction coordinator as guide. It was a bit of a struggle, but it was valuable to have someone there to give some guidance. It certainly helped to do a demo that no one needed to see before making one for the students to critique.

We created short piece on some basic chemical engineering databases and invited informal student feedback. Since the seniors were unavailable, we found some underclass students who agreed to look at it. They asked a very good question: what happens if one does not have Captivate available from the computer being used? We did some investigating and found that not all university computers have Captivate on it so it is reasonable to assume that students' personal computers might not have it. We are not giving up on the Captivate options but are taking a look at other options acceptable to our systems department so the video can be available in other formats.

\section{Where we are and what we do from here}

This project has not made it to completion. The senior chemical engineering students and the engineering librarian were unable to meet before the end of the fall semester. However, we solicited some informal comments from engineering students who work in the library and some of their engineering peers. Their comments were helpful (length of section too long, pace too slow, too much explanation) and allowed us to make some immediate changes. At the beginning of the spring semester, the chemical engineering seniors were contacted to view the modified video but did not respond. So once again the student workers and their peers were contacted and agreed to look at the module. Their comments are expected after spring break.

The projected timeline was off. It is taking much longer than anticipated. We did not schedule enough time to finish each piece of the video nor did we take into account how busy the students are in their last year of undergraduate coursework. The students' time is extremely valuable since they are balancing all that they are doing to finish their coursework, graduate on time and enjoy their senior year at the university. A senior class of nine students did not give us enough people to sample so we will expand it to all chemical engineering majors. We also discovered that it is more time-effective to send any video out for response than to try to bring everyone together in one place at the same time. Measurement and assessment of the project will come after we complete the video and document the responses.

Since the time for the project has expanded, we are taking the time to decide what other formats we might want to use for the video. We have not used the Flip camera for this project yet. We have done some testing with the camera and have used it for conference presentations we should 
be able to use it in a module if we choose to do so. We are not allowed to put YouTube video in our LibGuides; so we are looking for other options in that area as well. Since it is planned to use videos in other engineering LibGuides in the coming months, this is a work under construction.

\section{References}

1. Barsky, E., \& Lindstrom, K. (2008). Podcasting the sciences: A practical overview. Issues in Science \& Technology Librarianship, (55) Retrieved from http://search.ebscohost.com/login.aspx?direct=true\&db=1lh\&AN=BLIB09100730\&site=ehost-live; http://www.istl.org/08-fall/article7.html; http://www.podbean.com;/ http://www.pewinternet.org/PPF/r/193/report; http://www.emarketer.com/Article.aspx?id=1005869\&src=article1

2. Berger, E. (2007). Podcasting in engineering education: A preliminary study of content, student attitudes, and impact. Innovate: Journal of Online Education, 4(1) Retrieved from http://search.ebscohost.com/login.aspx?direct=true \&db=eric\&AN=EJ842348\&site=ehost-live; http://www.innovateonline.info/index.php?view=article\&id=426

3. Blummer, B. A., \& Kritskaya, O. (2009). Best practices for creating an online tutorial: A literature review. Journal of Web Librarianship, 3(3), 199-216. doi:10.1080/19322900903050799

3. Ganster, L. A., \& Walsh, T. R. (2008). Enhancing library instruction to undergraduates: Incorporating online tutorials into the curriculum. College \& Undergraduate Libraries, 15(3), 314-333.

doi:10.1080/10691310802258232

4. Kearns, K., \& Hybl, T. T. (2005). A collaboration between faculty and librarians to develop and assess a science literacy laboratory module. Science \& Technology Libraries, 25(4), 39-56. doi:10.1300/J122v25n04•04

5. Maness, J. (2006). Library 2.0 Theory: Web 2.0 and its implications for libraries. Webology, 3(2), article 25. Retrieved from http://www.webology.ir/2006/v3n2/a25.html

6. Maness, J. M. (2006). An evaluation of library instruction delivered to engineering students using streaming video. Issues in Science \& Technology Librarianship, (48), 6-6. Retrieved from http://search.ebscohost.com/login.aspx?direct=true \&db=ehh\&AN=22189393\&site=ehost-live

7. Michel, J. P., Hurst, S., \& Revelle, A. (2009). Vodcasting, iTunes U, and faculty collaboration. Electronic Journal of Academic \& Special Librarianship, 10(1), 6-6. Retrieved from http://search.ebscohost.com/login.aspx?direct=true\&db=lxh\&AN=41534766\&site=ehost-live

8. Osif, B.A., and DeSantis, S.M. (2005). Engineering resources tutorial [Video tutorial]. Penn State University Instructional Programs (Producer). Retrieved from http://www.libraries.psu.edu/instruction/engineering/engineering.html

9. Oud, J. (2009). Guidelines for effective online instruction using multimedia screencasts. Reference Services Review, 37(2), 164-177. Retrieved from http://search.ebscohost.com/login.aspx?direct=true \&db=lxh\&AN=42009106\&site=ehost-live

10. Roberts, J. C., \& Bhatt, J. (2007). Innovative approaches to information literacy instruction for engineering undergraduates at drexel university. European Journal of Engineering Education, 32(3), 243-251.

doi:10.1080/03043790701276171

11. Scaramozzino, J. M. (2008). An undergraduate science information literacy tutorial in a web 2.0 world. Issues in Science \& Technology Librarianship, (55), 3-3. Retrieved from http://search.ebscohost.com/login.aspx?direct=true \&db=lxh\&AN=35721410\&site=ehost-live 
12. Slebodnik, M., \& Zeidman-Karpinski, A. (2008). Resources for information literacy instruction in the sciences. Issues in Science \& Technology Librarianship, (54), 7-7. Retrieved from

http://search.ebscohost.com/login.aspx?direct=true \&db=lxh\&AN=34244725\&site=ehost-live 